\title{
Research on Information Literacy Standards of Military Flight
}

\author{
Lishu Zhang \\ Library \\ Aviation University of Airforce \\ Jilin, China \\ Ziran Zhang \\ Library \\ Aviation University of Airforce \\ Jilin, China
}

\author{
Lili Zhao \\ Library \\ Aviation University of Airforce \\ Jilin, China \\ Ji Qi \\ Legal Section \\ Tonghua People's Government \\ Jilin, China
}

\begin{abstract}
In the age of information warfare, information literacy of military flight will influence the outcome of war directly. Therefore, it is crucial to enhance military flight's information literacy. What are the elements of the military flight's information literacy standards? What is the present situation of the military flight's information literacy? How to carry out research on military flight's information literacy? All of these are realistic problems that military educators are facing. To figure out the above mentioned problems, the author carried out researches on literature research method, survey research method, SPSS statistical methods and so on. This paper focuses on the above questions and fulfills the following tasks: 1 . The current situation of the research on Information Literacy Competency Standards; 2. The construction of Military Flight's Information Literacy; 3. The investigation and statistical analysis of military flight crew information literacy.
\end{abstract}

\section{Keywords-military flight; information literacy; SPSS}

\section{INTRODUCTION}

The feature of the future war shows the trend of weapon accuracy, battle command, battle in the air, and fight integration. Battlefield in the air should be interactive with the command system and information support system of the army. Military pilots in today in will be future fighter, commander and leader of air battlefield in the future. The quality of information literacy will has effect on the war. Therefore, a standard and evaluation to military flight information literacy is needed.

\section{A. Research on the Standards of Information Literacy Competency}

The United States National Forum on information literacy defines "information literacy" as "the ability to know when there is a need for information and identify, locate, evaluate and use the information effectively for the problems at hand." Other definitions incorporate aspects of "skepticism, judgment, free thinking, questioning and understanding". A lot of efforts have been made to have a better definition of the concept and its relationship with other skills and forms of literacy. Although other educational goals including traditional literacy and computer literacy are related to information literacy and are important foundations for its development, information literacy itself is emerging as a distinct skill set and the key to one's social and economic well-being in an increasingly complex information society. According to McTavish, in order to increase and maximize people's contributions to a healthy, democratic and pluralistic society, and maintain prosperous and sustainable economic development, governments and industries around the world are challenging education systems to focus people's attention on literacy. In Canada, a great focus on a supposed literacy crisis has raised alarms in educational sector. Brink researched government organization, such as Human Resources and Skill Development Canada, claims that almost half of working-age Canadians do not have the literacy skills that they need to meet the ever-increasing demands of modern life.

\section{B. Research on Standard of Information Literacy Capacity}

In the following competencies, there are five standards and twenty-two performance indicators. The standards focus upon the needs of students in higher education at all levels. The standards also include a range of outcomes for helping student to progress in information literacy. These outcomes serve as guidelines for faculty, librarians and others in developing local methods for measuring student learning in the context of an institution's unique mission. In addition to assessing all student's basic information literacy, faculties and librarians should also work together to develop assessment instruments and strategies in the context of particular discipline, as information literacy manifests itself in the specific understanding of the knowledge creation, academic activities, and publication processes found in those disciplines. 
There are nine standards of information literacy for student learning.

- Standard 1: Students who are information literates access information efficiently and effectively.

- Standard 2: Students who are information literates evaluate information critically and competently.

- Standard 3: Student who are information literates use information accurately and creatively.

- Standard 4: Student who are independent learners are information literate and pursue information related to personal interests

- Standard 5: Student who are independent learners are information literate and appreciate literature and other creative expressions of information.

- Standard 6: Student who are independent learners are information literate and strive for excellence in information seeking and knowledge generation.

- Standard 7: Students who contribute positively to the learning community and society are information literate and recognize the importance of information to a democratic society.

- Standard 8: Students who contribute positively to the learning community and society are information literate, and practice ethical behavior in regard to information and information technology.
- Standard 9: Student who contribute positively to the learning community and society are information literates and participate effectively in groups to pursue and generate information.

\section{CONSTRUCTION OF MILITARY FLIGHT'S INFORMATION LITERACY}

\section{A. Connotation of Military Flight's Information Literacy}

Military flight crews refer to plane and other aircraft pilots. One seat plane pilot is only responsible for driving, the one is responsible for navigating, communicating and shooting. Pilots have strong interests in flying. They should possess broad mind, stable emotion and high IQ.

Combined with the basic concept of information literacy and main character of military flight, military flight's information literacy should be that military flight can collect and analyze information by using sensing technique no matter in the air or ground, wartime or peacetime, communication and web technique.

Connotation of Military Flight Information Literacy includes information consciousness, information knowledge, information skills, information moral and information security. They have the ability to access efficient information and choose information critically, as shown in "Fig. 1".

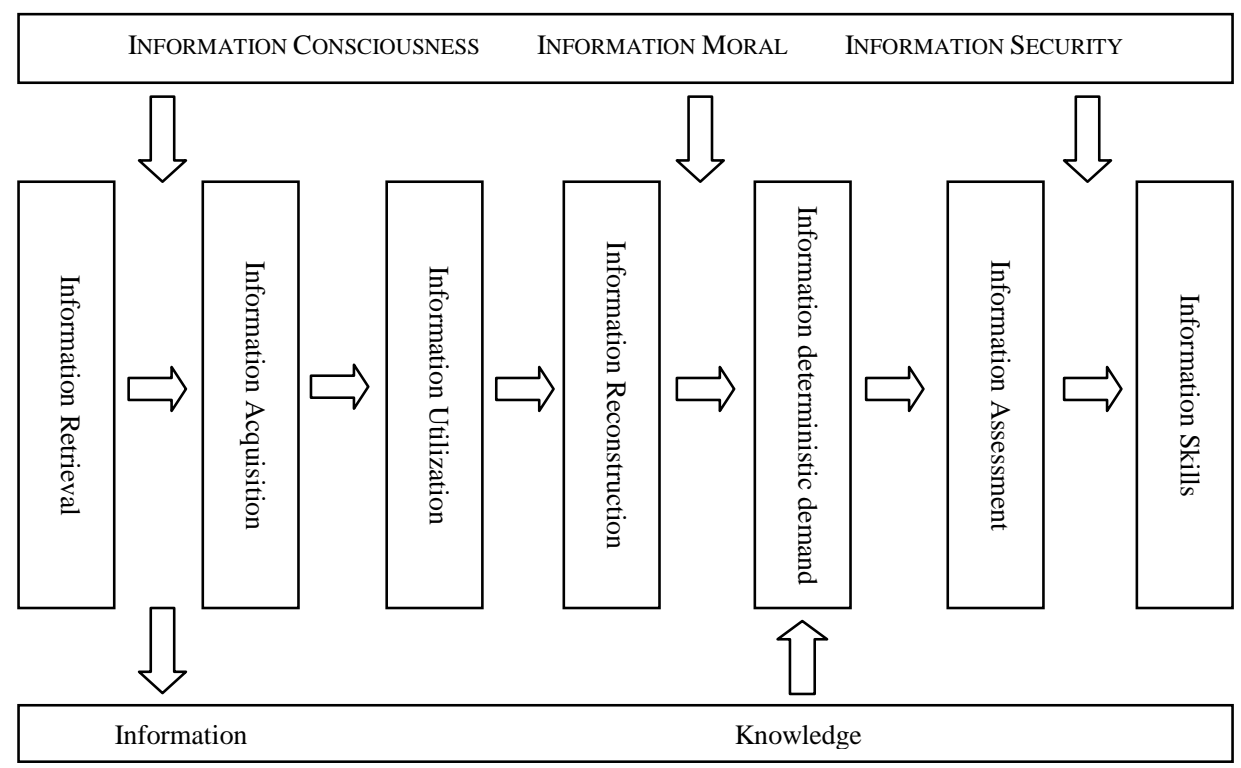

Fig. 1. Basic framework of military flight's information literacy standard.

\section{B. Correct Understanding of the Role of Information Literacy Enhancement to Military Flight}

1) It can improve military flights' ability to analyze information correctly: Military flight crew must make the right decision, which comes from the correct and timely analysis of information in the battlefield. The ability of judgment and analysis which comes from and the improvement of information literacy can help military flight crew get correct information from the complicated battlefield. 
2) It can improve military flight crew personnel command art and military strategy level: Information warfare is the decision-making control and knowledge warfare, which cannot be separated from the use of strategy. In future information battlefield, the strategy contest around the acquisition and anti-acquisition of information will be, unusually, intense and complex. Getting information by network teaching can improve the knowledge structure and the level of command art of military flight crews.

3) It can improve military flight crews' thinking level to adapt information warfare: With the development of $\mathrm{C}^{4} \mathrm{I}$ system, the application and popularization of all kinds of communication tools certainly cause the change of thinking field, and give a new connotation to the thinking of military flight crews. The improvement of information literacy can make military flight crew with a clear thinking in the information battlefield. They can make the right judgments and decisions according to different situations.

4) It can build composite knowledge structure for military flight crew:Information technology will fill every corner into future information warfare. High-tech weapons will be a combination of science and military knowledge. If there is no higher information literacy, but a simple military expertise. Military flight crew is clearly not competent. They must be comprehensive talents familiar with all kinds of knowledge. The improvement of information literacy can provide a platform for the cultivation of comprehensive military flight crew by making full use of various advantage information resources.

5) It can improve the mental and physical endurance of military flight crews: Military flight crews must have continuous fighting ability in information age warfare. This ability will not be shortened even in the rain or fog. It requires that military flight crews can endure tension activities psychologically and physiologically. Military flight crews can improve mental and physical endurance by the promotion of information literacy.

6) It can improve the ability of military flight crew to use the new generation fighter planes: A new generation fighter planes loaded with advanced computer equipment and network communication equipment. It requires military flight crews must be proficient in computer operation. Military flight crews can control all kinds of advanced computer and terminal equipment and fly new generation fighter planes by the promotion of information literacy.

At present, there is not a complete information literacy standard for military flight crews. With continuous improvement of information levels in warfare, it is extremely urgent to construct a set of complete military flight crew Information Literacy Standards for military flight crew training needs.

Formulation of information literacy standards for military flight crew will provide a basis for military flight schools to make operable information literacy assessment systems. The assessment criteria will become a guide for teaching and student learning in military flight schools, and it will also become an education assessment basis for ministry of education. The formulation of information literacy standards should proceed from the actual information construction ability of our military schools and absorb advanced experience and achievements abroad.

On the basis of interpreting the connotation and the basic framework of the military flight crew information literacy completely, it also draws lessons from domestic and international information literacy standards system, the author designs and constructs military flight crew information literacy standards, the research group makes a further study and the expert gives feedback. Standard system includes five dimensions, 15 performance indicators and 40 indexes, specific description as shown in "Table I". 
TABLE I.

"RESEARCH ON INFORMATION LITERACY COMPETENCY STANDARDS OF MILITARY FLYING CREW" CONSULTING QUESTIONNAIRE

\begin{tabular}{|c|c|c|c|c|c|}
\hline \multirow{2}{*}{ Standards } & \multirow{2}{*}{ Indexes } & \multirow{2}{*}{ Indexes Description } & \multicolumn{2}{|c|}{ Need } & \multirow{2}{*}{$\begin{array}{c}\text { No } \\
\text { Need }\end{array}$} \\
\hline & & & Important & Common & \\
\hline \multirow{5}{*}{$\begin{array}{l}\text { Information } \\
\text { consciousness }\end{array}$} & \multirow{3}{*}{$\begin{array}{l}\text { Information } \\
\text { cognition }\end{array}$} & $\begin{array}{l}\text { Aware of the importance of information,maintain a positive attitude towards information } \\
\text { that used to support learning, master flight skills and enhance combat power. }\end{array}$ & & & \\
\hline & & $\begin{array}{l}\text { Understand the value of various sources of information (e.g. web, libraries, and other } \\
\text { media) and the products and services provided by information organization. }\end{array}$ & & & \\
\hline & & $\begin{array}{l}\text { Recognize that information literacy is an essential ability to win the information war in } \\
\text { future. }\end{array}$ & & & \\
\hline & $\begin{array}{l}\text { Information } \\
\text { emotion }\end{array}$ & $\begin{array}{l}\text { consciously produce information needs, experience the cultural connotation of information } \\
\text { technology. } \\
\text { stimulate and maintain appetite for information technology knowledge. } \\
\text { form a positive and active information technology learning attitude and participate in } \\
\text { information activities. }\end{array}$ & & & \\
\hline & $\begin{array}{l}\text { Information } \\
\text { sensitivity }\end{array}$ & $\begin{array}{l}\text { To capture information from a rapidly changing situation, to discover valuable information } \\
\text { from a common phenomenon. } \\
\text { In wartime, one step ahead to seize the opportunity, to succeed, in an invincible position. }\end{array}$ & & & \\
\hline \multirow{7}{*}{$\begin{array}{l}\text { Information } \\
\text { knowledge }\end{array}$} & \multirow{5}{*}{$\begin{array}{l}\text { Information } \\
\text { theory }\end{array}$} & $\begin{array}{l}\text { To know the working principle of the computer and the composition of the operating } \\
\text { system }\end{array}$ & & & \\
\hline & & Understand network theory, database technology and artificial intelligence & & & \\
\hline & & $\begin{array}{l}\text { Familiar with the history of the information technology development, understanding the } \\
\text { development trend of information technology. }\end{array}$ & & & \\
\hline & & Understand the nature, characteristics and operational pattern of information warfare & & & \\
\hline & & $\begin{array}{l}\text { master the basic knowledge of joint operations, information security, aircraft and related } \\
\text { weapons equipment knowledge, etc. }\end{array}$ & & & \\
\hline & \multirow{2}{*}{$\begin{array}{l}\text { Information } \\
\text { practice }\end{array}$} & Familiar with computer basic operation. & & & \\
\hline & & Master a programming language, multimedia technology and network technology & & & \\
\hline \multirow{13}{*}{$\begin{array}{l}\text { Information } \\
\text { technology }\end{array}$} & \multirow{4}{*}{$\begin{array}{l}\text { Information } \\
\text { retrieval } \\
\text { ability }\end{array}$} & To clearly describe the information needs. & & & \\
\hline & & Identify key words, synonyms, and specialized terms for information needed. & & & \\
\hline & & $\begin{array}{l}\text { Determine the scope of possible sources of information in accordance with the purposes, } \\
\text { appropriateness, functions and forms of required information. }\end{array}$ & & & \\
\hline & & Build an appropriate search type. & & & \\
\hline & \multirow{3}{*}{$\begin{array}{l}\text { Ability to } \\
\text { acquire } \\
\text { information }\end{array}$} & $\begin{array}{l}\text { Use different information retrieval systems to retrieve information of different carriers and } \\
\text { formats. }\end{array}$ & & & \\
\hline & & $\begin{array}{l}\text { Search for information resources in libraries or other information institutions by using } \\
\text { different classification methods or other retrieval systems }\end{array}$ & & & \\
\hline & & $\begin{array}{l}\text { Use surveys, communications, interviews, discussions and other ways to get the main } \\
\text { information. }\end{array}$ & & & \\
\hline & \multirow{2}{*}{$\begin{array}{l}\text { Processing } \\
\text { information } \\
\text { ability }\end{array}$} & $\begin{array}{l}\text { Be able to understand the information found, to grasp the information to meet the needs of } \\
\text { the specific value }\end{array}$ & & & \\
\hline & & $\begin{array}{l}\text { Have the ability to complete the process of information integration on the basis of } \\
\text { information collection. }\end{array}$ & & & \\
\hline & \multirow{2}{*}{$\begin{array}{l}\text { Information } \\
\text { cooperation } \\
\text { ability }\end{array}$} & effectively communicate and exchange information products. & & & \\
\hline & & Ability to communicate and deliver information within the organization. & & & \\
\hline & \multirow{2}{*}{$\begin{array}{l}\text { Information } \\
\text { evaluation } \\
\text { skill }\end{array}$} & $\begin{array}{l}\text { Be able to evaluate the reliability, accuracy, authority and timeliness of information and } \\
\text { information sources. }\end{array}$ & & & \\
\hline & & $\begin{array}{l}\text { Be able to evaluate your own and other people's information activities, can summarize the } \\
\text { basic ideas and methods of information technology to solve the problem. }\end{array}$ & & & \\
\hline \multirow{5}{*}{$\begin{array}{l}\text { information } \\
\text { ethics }\end{array}$} & \multirow{3}{*}{$\begin{array}{l}\text { Information } \\
\text { ethics and } \\
\text { law }\end{array}$} & $\begin{array}{l}\text { Following the information law, resisting illegal information behavior, not making, } \\
\text { spreading, using bad information. }\end{array}$ & & & \\
\hline & & Maintain the integrity of information resources, equipment, systems and related facilities. & & & \\
\hline & & Legally Get, spread text, data, image and sound information & & & \\
\hline & \multirow{2}{*}{$\begin{array}{l}\text { intellectual } \\
\text { property } \\
\text { right }\end{array}$} & $\begin{array}{l}\text { Understand of intellectual property rights, respect for other people's information property } \\
\text { rights, legitimate use of copyrighted material }\end{array}$ & & & \\
\hline & & Have a good spirit of cooperation, respect other people's privacy & & & \\
\hline \multirow{7}{*}{$\begin{array}{l}\text { Information } \\
\text { security }\end{array}$} & \multirow{5}{*}{$\begin{array}{l}\text { Information } \\
\text { security } \\
\text { knowledge }\end{array}$} & $\begin{array}{l}\text { Understand and master the basic concepts, level, scope and existing form of military } \\
\text { secrets. }\end{array}$ & & & \\
\hline & & Understand the hidden dangers of various communication methods. & & & \\
\hline & & Understand the main means of stealing secrets by network. & & & \\
\hline & & Understand the characteristics and preventive measures of anti virus and Trojan software & & & \\
\hline & & understand the main risk of network information transmission & & & \\
\hline & \multirow{2}{*}{$\begin{array}{l}\text { Information } \\
\text { security } \\
\text { awareness }\end{array}$} & Understand the severe situation and challenges of information security and confidentiality & & & \\
\hline & & Understand the status and role of information security and confidentiality & & & \\
\hline
\end{tabular}




\section{INVESTIGATION AND STATISTICAL ANALYSIS OF MILITARY FLIGHT CREW INFORMATION LITERACY}

\section{A. Scale Compilation and Testing}

Military flight crew information literacy status questionnaire is going to contact the five dimensions of the standards in order to obtain a comprehensive understanding of the military crew information literacy status from different angles.

We choose Richter (Likert) five point scales for its better internal consistency to design the questionnaire. According to the subject described in the questionnaire, people who was tested to check one of the most in line with their own in five different options. According to the option weight, and were given 5 points, 4 points, 3 points, 2 points and 1 points, the sum of all the scores, for their attitude scores, the higher the score, the higher the information literacy.

The questionnaire is divided into part $\mathrm{A}$ and part $\mathrm{B}, 48$ questions. Part A consists of 3 questions, the title form is "A + number", it is a multiple-choice question in order to understand the background of tested people. Part B consists of 45 questions which is the main body of the questionnaire, the title form is "B + number", the scientific verification part is part B. Part A is for background information to understand and do not serve as scientific verification.

Military crew of a flight academy was chosen to participate the test. We issued 126 sample copies and received 126 copies. Some papers do not answer seriously and some papers do not answer as required. We give up those papers - 104 valid questionnaires, the effective rate is $82.5 \%$. In order to illustrate the problem effectively, we keep some papers without answers which are calculated by 0 point.

\section{B. SPSS Statistical Analysis of the Questionnaire}

All the survey results were managed by SPSS17.0 statistic software, and SPSS was used for data processing and statistic analysis of the prediction results. SPSS is a famous analysis of statistic software in the world, and it has become the most commonly used tool for domestic education and scientific research since 1998 in the promotion use of colleges and universities. SPSS17.0 is the latest version of the software. The analysis includes descriptive statistics, $\mathrm{T}$ tests, factor analysis, reliability analysis, correlation analysis, project analysis and so on.

1) Project analysis: Rescore the reverse question in the questionnaire. Counting the total score of the 45 questions, ranking all 126 papers according to the level of the total score. The total score is higher than 185 points as high group (first group), the total score less than 150 is taken as a low group (second group), each group is 28 people. T test was used to test the difference between the two groups of data.

"Table II" is two independent samples of the mean test results with $\mathrm{T}$ test. The second column is to test the observed value of $F$ statistic. The third column is the corresponding probability value $P$. If $\operatorname{sig}>0.05$, it can be considered that there is no significant difference between the two equal variances. Therefore, $T$ test results should be made in case of equal variance. To observe the bilateral probability $p$ value of the fifth column according to this method, in case of significant $(\operatorname{sig}<0.05)$, the question could be considered. Statistical results show that B2, B3, B4, B6, B9, B39 do not reach the statistical significant level, they should be excluded. Other items with a better degree of division can enter the next factor analysis.

TABLE II. INDEPENDENT SAMPLE TEST

\begin{tabular}{|c|c|c|c|c|c|c|c|c|}
\hline & & \multicolumn{2}{|c|}{\begin{tabular}{|c} 
Levene Test Of Variance \\
Equation
\end{tabular}} & \multicolumn{5}{|c|}{ T Test For Mean Value Equation } \\
\hline & & $\boldsymbol{F}$ & Sig. & $t$ & $d f$ & Sig. & $\begin{array}{c}\text { mean value } \\
\text { Difference value }\end{array}$ & $\begin{array}{c}\text { Standard error } \\
\text { value }\end{array}$ \\
\hline \multirow[t]{2}{*}{ B1 } & Equal variances assumed & 21.753 & .000 & 2.280 & 26 & .031 & .429 & .188 \\
\hline & Equal variances not assumed & & & 2.280 & 17.268 & .036 & .429 & .188 \\
\hline \multirow[t]{2}{*}{ B2 } & Equal variances assumed & 4.023 & .055 & 1.561 & 26 & .131 & .429 & .275 \\
\hline & Equal variances not assumed & & & 1.561 & 19.399 & .135 & .429 & .275 \\
\hline \multirow[t]{2}{*}{ B3 } & Equal variances assumed & 2.645 & .116 & 1.555 & 26 & .132 & .571 & .367 \\
\hline & Equal variances not assumed & & & 1.555 & 19.039 & .136 & .571 & .367 \\
\hline \multirow[t]{2}{*}{ B4 } & Equal variances assumed & 16.153 & .000 & 1.930 & 26 & .065 & 1.000 & .518 \\
\hline & Equal variances not assumed & & & 1.930 & 18.881 & .069 & 1.000 & .518 \\
\hline \multirow[t]{2}{*}{ B5 } & Equal variances assumed & 10.497 & .003 & 3.633 & 26 & .001 & 1.643 & .452 \\
\hline & Equal variances not assumed & & & 3.633 & 17.127 & .002 & 1.643 & .452 \\
\hline \multirow[t]{2}{*}{ B6 } & Equal variances assumed & .860 & .362 & 1.561 & 26 & .131 & .429 & .275 \\
\hline & Equal variances not assumed & & & 1.561 & 23.962 & .132 & .429 & .275 \\
\hline \multirow[t]{2}{*}{ B7 } & Equal variances assumed & 1.814 & .190 & 2.174 & 26 & .039 & .857 & .394 \\
\hline & Equal variances not assumed & & & 2.174 & 23.400 & .040 & .857 & .394 \\
\hline
\end{tabular}




\begin{tabular}{|c|c|c|c|c|c|c|c|c|}
\hline \multirow[t]{2}{*}{ B8 } & Equal variances assumed & 4.981 & .034 & 4.316 & 26 & .000 & 1.071 & .248 \\
\hline & Equal variances not assumed & & & 4.316 & 19.462 & .000 & 1.071 & .248 \\
\hline \multirow[t]{2}{*}{ B9 } & Equal variances assumed & 2.170 & .153 & 1.100 & 26 & .282 & .286 & .260 \\
\hline & Equal variances not assumed & & & 1.100 & 24.909 & .282 & .286 & .260 \\
\hline \multirow[t]{2}{*}{ B10 } & Equal variances assumed & 19.843 & .000 & 2.797 & 26 & .010 & .786 & .281 \\
\hline & Equal variances not assumed & & & 2.797 & 17.917 & .012 & .786 & .281 \\
\hline \multirow[t]{2}{*}{ B11 } & Equal variances assumed & .845 & .366 & 2.252 & 26 & .033 & 1.214 & .539 \\
\hline & Equal variances not assumed & & & 2.252 & 25.614 & .033 & 1.214 & .539 \\
\hline \multirow[t]{2}{*}{ B12 } & Equal variances assumed & .319 & .577 & 4.544 & 26 & .000 & 1.643 & .362 \\
\hline & Equal variances not assumed & & & 4.544 & 25.830 & .000 & 1.643 & .362 \\
\hline \multirow[t]{2}{*}{ B13 } & Equal variances assumed & 6.269 & .019 & 5.394 & 26 & .000 & 1.857 & .344 \\
\hline & Equal variances not assumed & & & 5.394 & 19.185 & .000 & 1.857 & .344 \\
\hline \multirow[t]{2}{*}{ B14 } & Equal variances assumed & 1.468 & .237 & 2.880 & 26 & .008 & 1.214 & .422 \\
\hline & Equal variances not assumed & & & 2.880 & 23.462 & .008 & 1.214 & .422 \\
\hline \multirow[t]{2}{*}{ B15 } & Equal variances assumed & 4.333 & .047 & 6.745 & 26 & .000 & 2.000 & .296 \\
\hline & Equal variances not assumed & & & 6.745 & 20.800 & .000 & 2.000 & .296 \\
\hline \multirow[t]{2}{*}{ B16 } & Equal variances assumed & 4.115 & .053 & 6.488 & 26 & .000 & 1.786 & .275 \\
\hline & Equal variances not assumed & & & 6.488 & 24.047 & .000 & 1.786 & .275 \\
\hline \multirow[t]{2}{*}{ B17 } & Equal variances assumed & .506 & .483 & 6.204 & 26 & .000 & 2.143 & .345 \\
\hline & Equal variances not assumed & & & 6.204 & 25.839 & .000 & 2.143 & .345 \\
\hline \multirow[t]{2}{*}{ B18 } & Equal variances assumed & .110 & .743 & 4.341 & 26 & .000 & 1.357 & .313 \\
\hline & Equal variances not assumed & & & 4.341 & 24.705 & .000 & 1.357 & .313 \\
\hline \multirow[t]{2}{*}{ B19 } & Equal variances assumed & 3.310 & .080 & 5.749 & 26 & .000 & 2.143 & .373 \\
\hline & Equal variances not assumed & & & 5.749 & 20.847 & .000 & 2.143 & .373 \\
\hline \multirow[t]{2}{*}{ B20 } & Equal variances assumed & .435 & .515 & 7.317 & 26 & .000 & 1.929 & .264 \\
\hline & Equal variances not assumed & & & 7.317 & 25.226 & .000 & 1.929 & .264 \\
\hline \multirow[t]{2}{*}{ B21 } & Equal variances assumed & .544 & .467 & 5.905 & 26 & .000 & 1.786 & .302 \\
\hline & Equal variances not assumed & & & 5.905 & 25.704 & .000 & 1.786 & .302 \\
\hline \multirow[t]{2}{*}{$\mathrm{B} 22$} & Equal variances assumed & 2.769 & .108 & 4.000 & 26 & .000 & 1.143 & .286 \\
\hline & Equal variances not assumed & & & 4.000 & 20.156 & .001 & 1.143 & .286 \\
\hline \multirow[t]{2}{*}{ B23 } & Equal variances assumed & 10.588 & .003 & 4.412 & 26 & .000 & 1.214 & .275 \\
\hline & Equal variances not assumed & & & 4.412 & 19.363 & .000 & 1.214 & .275 \\
\hline \multirow[t]{2}{*}{ B24 } & Equal variances assumed & .812 & .376 & 2.158 & 26 & .040 & .857 & .397 \\
\hline & Equal variances not assumed & & & 2.158 & 18.833 & .044 & .857 & .397 \\
\hline \multirow[t]{2}{*}{ B25 } & Equal variances assumed & 2.769 & .108 & 7.000 & 26 & .000 & 2.000 & .286 \\
\hline & Equal variances not assumed & & & 7.000 & 20.156 & .000 & 2.000 & .286 \\
\hline \multirow[t]{2}{*}{ B26 } & Equal variances assumed & .273 & .606 & 5.003 & 26 & .000 & 1.500 & .300 \\
\hline & Equal variances not assumed & & & 5.003 & 23.359 & .000 & 1.500 & .300 \\
\hline \multirow[t]{2}{*}{ B27 } & Equal variances assumed & .017 & .897 & 4.056 & 26 & .000 & 1.286 & .317 \\
\hline & Equal variances not assumed & & & 4.056 & 25.975 & .000 & 1.286 & .317 \\
\hline B28 & Equal variances assumed & 9.887 & .004 & 5.302 & 26 & .000 & 1.786 & .337 \\
\hline & Equal variances not assumed & & & 5.302 & 21.229 & .000 & 1.786 & .337 \\
\hline B29 & Equal variances assumed & .022 & .884 & 2.879 & 26 & .008 & 1.071 & .372 \\
\hline & Equal variances not assumed & & & 2.879 & 21.523 & .009 & 1.071 & .372 \\
\hline B30 & Equal variances assumed & 1.725 & .201 & 6.666 & 26 & .000 & 1.500 & .225 \\
\hline & Equal variances not assumed & & & 6.666 & 22.722 & .000 & 1.500 & .225 \\
\hline B31 & Equal variances assumed & 9.381 & .005 & 5.696 & 26 & .000 & 2.071 & .364 \\
\hline & Equal variances not assumed & & & 5.696 & 19.679 & .000 & 2.071 & .364 \\
\hline B32 & Equal variances assumed & .484 & .493 & 3.631 & 26 & .001 & 1.214 & .334 \\
\hline & Equal variances not assumed & & & 3.631 & 22.788 & .001 & 1.214 & .334 \\
\hline
\end{tabular}




\begin{tabular}{|c|c|c|c|c|c|c|c|c|}
\hline \multirow[t]{2}{*}{ B33 } & Equal variances assumed & 1.317 & .261 & 5.342 & 26 & .000 & 1.643 & .308 \\
\hline & Equal variances not assumed & & & 5.342 & 23.002 & .000 & 1.643 & .308 \\
\hline \multirow[t]{2}{*}{ B34 } & Equal variances assumed & 5.992 & .021 & 5.270 & 26 & .000 & 1.357 & .258 \\
\hline & Equal variances not assumed & & & 5.270 & 21.337 & .000 & 1.357 & .258 \\
\hline \multirow[t]{2}{*}{ B35 } & Equal variances assumed & 9.113 & .006 & 4.655 & 26 & .000 & 1.429 & .307 \\
\hline & Equal variances not assumed & & & 4.655 & 19.118 & .000 & 1.429 & .307 \\
\hline \multirow[t]{2}{*}{ B36 } & Equal variances assumed & 6.768 & .015 & 3.232 & 26 & .003 & 1.500 & .464 \\
\hline & Equal variances not assumed & & & 3.232 & 16.604 & .005 & 1.500 & .464 \\
\hline \multirow[t]{2}{*}{ B37 } & Equal variances assumed & 5.492 & .027 & 2.416 & 26 & .023 & 1.143 & .473 \\
\hline & Equal variances not assumed & & & 2.416 & 16.738 & .027 & 1.143 & .473 \\
\hline \multirow[t]{2}{*}{ B38 } & Equal variances assumed & 3.894 & .059 & 4.300 & 26 & .000 & 1.143 & .266 \\
\hline & Equal variances not assumed & & & 4.300 & 21.350 & .000 & 1.143 & .266 \\
\hline \multirow[t]{2}{*}{ B39 } & Equal variances assumed & .791 & .382 & 1.465 & 26 & .155 & .786 & .536 \\
\hline & Equal variances not assumed & & & 1.465 & 25.731 & .155 & .786 & .536 \\
\hline \multirow[t]{2}{*}{ B40 } & Equal variances assumed & 5.483 & .027 & 3.442 & 26 & .002 & .857 & .249 \\
\hline & Equal variances not assumed & & & 3.442 & 19.417 & .003 & .857 & .249 \\
\hline \multirow[t]{2}{*}{ B41 } & Equal variances assumed & 6.539 & .017 & 3.053 & 26 & .005 & 1.286 & .421 \\
\hline & Equal variances not assumed & & & 3.053 & 18.049 & .007 & 1.286 & .421 \\
\hline \multirow[t]{2}{*}{ B42 } & Equal variances assumed & 19.792 & .000 & 3.162 & 26 & .004 & .714 & .226 \\
\hline & Equal variances not assumed & & & 3.162 & 15.854 & .006 & .714 & .226 \\
\hline \multirow[t]{2}{*}{ B43 } & Equal variances assumed & 4.535 & .043 & 5.255 & 26 & .000 & 1.643 & .313 \\
\hline & Equal variances not assumed & & & 5.255 & 17.800 & .000 & 1.643 & .313 \\
\hline \multirow[t]{2}{*}{ B44 } & Equal variances assumed & .502 & .485 & 3.882 & 26 & .001 & 1.929 & .497 \\
\hline & Equal variances not assumed & & & 3.882 & 25.879 & .001 & 1.929 & .497 \\
\hline \multirow[t]{2}{*}{ B45 } & Equal variances assumed & 20.814 & .000 & 2.736 & 26 & .011 & .857 & .313 \\
\hline & Equal variances not assumed & & & 2.736 & 14.422 & .016 & .857 & .313 \\
\hline
\end{tabular}

2) Factor analysis: The above identified 39 questions (B2, B3, B4, B6, B9, B39 excluded) will be used as factor analysis. KMO and Bartlett 's test are needed before factor analysis. The higher of KMO, the more common factors among the variables, and the more suitable for factor analysis.

\section{TABLE III. BARTLETT 'S AND KMO TEST FOR INFORMATION} LITERACY QUESTIONNAIRE

\begin{tabular}{|l|l|l|}
\hline \multirow{2}{*}{ Kartlett } & 0.671 \\
& Kaiser-Meyer-Olkin & 1392.552 \\
\hline & hemispheric test value & 139 \\
\hline & Sig. & 741 \\
\hline
\end{tabular}

Specific result is shown in "Table III". Kmo value is 0.671 which is suitable for factor analysis, and Bartlett 's hemispheric test value is 1392.552 ( freedom degree $\mathrm{df}=741$ ) which reaches significant level $(\mathrm{Sig}=0.000)$. There is a common factor that suitable for factor analysis.

We find the slope of the line is significantly changed since the tenth factors through the observation of the gravel figure (Figure two), that indicates other factors playing a very small role. So it is appropriate to retain 5 to 10 factors. This paper retains five factors which were named as information knowledge (B1, B5, B7, B8, B10), information consciousness (B8, B21), information capacity (B22, B33), information ethics (B34, B35, B36,B37, B38), information security (B40, B41, B42, B43, B4B44, B45)4, B45).

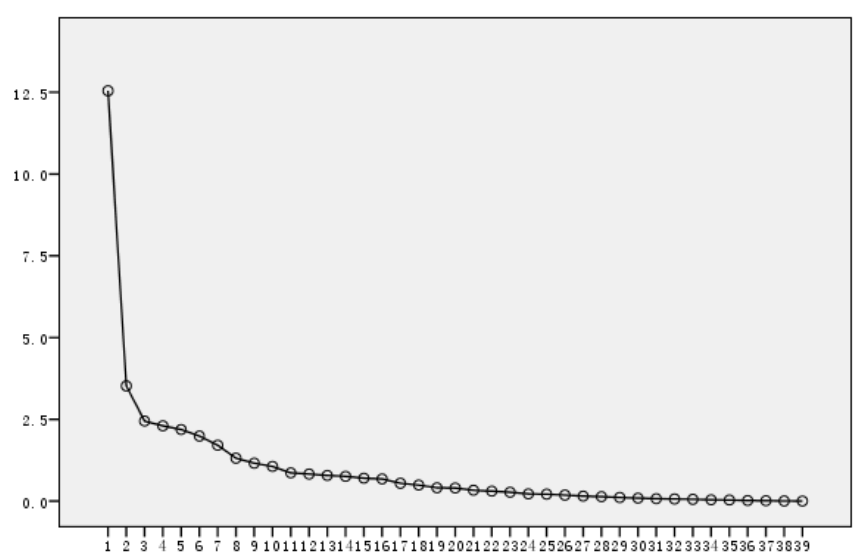

Fig. 2. Gravel figure.

3) Reliability Analysis: In order to understand the reliability and validity of the questionnaire, reliability test should be done after the completion of the structural validity analysis. In this study, the Cronbach $\alpha$ was used as the reliability test index. If the internal reliability $\alpha$ coefficient was above 0.8 (Bryman \& Cramer, 1997), the questionnaire would have a high degree of reliability. Through the SPSS 
analysis, the calculation of $\alpha$ reliability coefficient is 0.894 (as shown in table four), indicating that the questionnaire has a good reliability.

TABLE IV. TABLE FOUR: CRONBACH A COEFFICIENT RELIABILITY ANALYSIS

\begin{tabular}{|c|c|c|}
\hline $\begin{array}{c}\text { Cronbach's } \\
\text { Alpha }\end{array}$ & $\begin{array}{c}\text { Based on the standard term } \\
\text { Cronbach's Alpha }\end{array}$ & Number of terms \\
\hline 0.898 & 0.894 & 5 \\
\hline
\end{tabular}

4) Summary: Through the project analysis above, factor analysis and reliability analysis, scientific test results in line with expectations. The measurement tool is scientific and effective which can be used for data collection in the practical investigation activities.

\section{ANALYSIS OF FACTORS THAT AFFECT INFORMATION LITERACY}

\section{A. Background Data Analysis of Military Flight Crews}

Choosing background survey questions 1, 2, 3, to do relative research. "The economic situation of your family region" "Do you have a personal computer or a computer in your home" "Before you joined the army, have you ever been in contact with the Internet? "SPSS analysis on the three questions. The results show that the economic situation of the family area has a close relation with the computer owning, but the computer familiarity degree is not directly related to the computer owning. This shows that with the deepening of information technology degree, military crew is familiar with computer network, most people equipped with a certain knowledge in the computer network before joining the army.

\section{B. Current Situation of Information Consciousness}

In this part, 10 questions are arranged to test. In this part, the lowest scores were "How long do you surf the Internet every day? An hour or more?" and "Will you access to learning materials online?" The mean value is 2.33 points and 3.81 points respectively. This shows that current military school is not creating a good information environment atmosphere for military flight crews, which is a sharp contrast with the inner desire of military crew for information literacy.

\section{Present Situation of Information Knowledge}

In this part, 11 questions are arranged to test. The average score of each problem is between 2.65 and 3.67, and the standard deviation is also close. The lowest score is "Do you know the concept of the TCP / IP protocol, database, and topology?" "Do you know the concept of data chain, virtual simulation and its application?" and "Do you use blog to publish articles and works" and other problems. It shows that there is a big gap between the military flight crew in network and knowledge of the information frontier.

\section{Current Status of Information Skills}

In this part, 12 questions are arranged to test. The average score of each problem is between 3.1 and 4.12, and the lowest score two is "Can you determine the difference between each search content and reestablish a retrieval strategy?" and "When you're getting a lot of relevant professional knowledge from the network, will you summary and classify them?" The highest score is "in the learning process, can you determine the type and strategy of the information you need?" This shows that the network has become a main tool for student to search and exchange information in study and in life. But the ability of military flight crews to retrieve strategy and summarize information is weak, they can not migrate information to specific environment to solve problems effectively in study and working.

\section{E. Present Situation of Information Ethics}

In this part, 5 questions are arranged to test. The average score of each problem is between 3.94 to 4.15 points, the information literacy of military flight crew is higher. The lowest score is "when facing with information resources of the good and the bad, can you consciously resist and eliminate the garbage information and harmful information?" It shows that the abundant information resources on the Internet can stimulate students' initiative to learn and cultivate students' ability to store and use information resources. At the same time, "information rubbish" also increases the complexity of information retrieval and utilization. It weakens the ability of military crew to choose and judge information, which leads the lack of moral and legal consciousness of military pilots.

\section{F. Information Security Status}

In this part, 7 questions are arranged to test. The average score of each problem is between 2.46 to 4.65 points. The lowest score is "Once the disk is formatted, can you find the file?" and "Are you familiar with encryption, identity authentication, access control, firewall, intrusion detection and other security related technologies?" The rest of the scores were above 4 points, which shows that military crew have a higher sense of information security awareness, but information security skills should be improved.

\section{SUMmary OF EXISTING PROBLEMS}

Through the investigation, some problems exist in military crew information literacy ability training process. The author sums up as the following.

\section{A. There is No Unified Military Flight Crew Information literacy Assessment System}

So far, we have not set a standard military flight crew information literacy evaluation index system in our country and army.

\section{B. There Is No Good Environment For The Cultivation Of Military Flight Crew Information Literacy Ability}

Computer quantity is insufficient in computer room, the military flight crew average daily internet time is less than one hour, and time is less. Therefore, there is lack of good training environment. 


\section{Curriculum Structure Is Simple; the Information Literacy Training Content System is not Complete}

At present, most military flight colleges and universities have set up 《Computer Foundation》 and 《 Education Technology $\rangle$ course, but the computer technology education is not equal to the information literacy education. Military flight crew has problems in information ethics, there are still a lot of dead ends, so the establishment of a complete information literacy system is essential.

\section{Library Function Is Not Obvious}

Library should become the main force of information literacy cultivation for its abundant information retrieval knowledge. But from military flight crew current information literacy situation, the library function is obviously needed to be strengthen.

\section{THE WAYS AND COUNTERMEASURES OF THE IMPLEMENTATION STANDARD}

The implementation of the standard is not only the logical starting but also the ultimate destination of the standard research. At present, how to implement the information literacy education is becoming a hot topic of educational reform in all countries. In order to keep up with the international situation, this chapter does research on literacy status of military flight crew and finds out the standard implementation of the realistic environment. We analyse and discuss the framework which the standard should be implemented with, and how to take effective strategies to solve the problems.

\section{A. Construction of Evaluation Index System of Military Flight Crew Information Literacy}

Information literacy assessment is based on a certain purpose and standards. It is a process to inspect personal and organizational comprehensive information ability by using scientific attitude and methods. Specifically, it is to judge the extent and level of military flight crew information literacy of which is significance for them in the information society.

\section{B. Creating a Good Environment for Information Literacy Education}

The university should establish the comprehensive plan for students' information literacy education and make it receive widespread attention and support. The practice course in computer should be arranged more, so that the diversified teaching mode can be effectively integrated into the normal teaching. The knowledge learned in the information technology class can be applied timely. The whole process of education requires close cooperation of different professional teachers and librarians. For example, computer basic knowledge, network environment and related software will be charged by the computer teaching and research office. Network information resources, especially the collection and evaluation method of the literature information resources are offered by the library; law or moral education teachers will be charge the popularization of moral and legal knowledge.

\section{Optimization of Information Literacy Curriculum}

Opening special information technology courses according to the characteristics of military crew instead of requiring them to pass computer grade examination before graduation is accepted. With the development of information technology, military crew should have more comprehensive information literacy ability, so the curriculum should be set up to cultivate students' ability to find and use actual information, such as "literature information retrieval and utilization", "literature information retrieval under the environment of network", "information retrieval and paper writing", "basic computer operation", "computer network", "modern information technology", "educational technology", "information education", "information law" and other courses. The students have the ability to complete the learning process of these courses under the network environment, which has strong practicability and maneuverability.

\section{Playing the Role Of Library Fully}

The abundant information resources and professional information of the library play an irreplaceable role in students' information literacy education. Library should open the courses of "new students into the library education", "the use of foreign language database lectures", "Chinese library book classification"," network information navigation training" so the students can retrieve and use the network information technology by themselves.

\section{CONCLUSION}

This research report first sums up the military flight crew information literacy competency standards mode by literature reading, questionnaire investigation, interview, discussion and communication and SPSS statistical method. Flight college teachers and teaching experts and flight commanders also join the discussion. On this basis, this report not only shows the status of military flight crew information literacy from different angles in the light of shortcomings of the current military personnel training process, but also gives suggestions on military flight crew information literacy training mode. It is better for the further improvement of military educational technology disciplinary construction. It is a bridge from theory to practice which points out the direction for the establishment of military flight crew information literacy competency standards.

\section{REFERENCES}

[1] American Library Association [ALA]. (1998). Information power: the nine information literacy standards for student learning.

[2] Retrieved February5, 2001, from http://www.Ala.org/ aas1/ ip_nine.html.

[3] American Association of School Librarians [AASL] (1999). Information literary: A position paper on information problem solving.

[4] Retrieved December2, 2003, from http://www.ala.org/aasl/positions/ps_infolit.htm.

[5] Association of College and Research Libraries. (2007, May21) Information literacy competency standards for higher education. Retrieved October1.2007, from http:// 
[6] www.ala.org/ala/acrl/acrlstandards/information literacy competency.

[7] Jung, S., Herlocker, J.L \& Webster,J.(2007).Click data as implicit relevance feedback in web search. Information Processing \& Management, 43,791-807. Retrieved October1.2007, from LISTA.

[8] Gloria J. Leckie \& Anne Fullerton, Information Literacy in Science and Engineering Undergraduate Education: Faculty Attitudes and Pedagogical Practices, College \& Research Libraries 60(Jan.1999):930.

[9] Doyle, C. (1994). Information literacy in an information society: a concept for the information age. Syracuse, NY: ERIC clearing house on Information resources, ED372763.

[10] Brown and Krumholz, Distance students and online research: Promoting information literacy through media literacy. The internet and Higher Education 13(June 2010): 170-175.

[11] Clark, Irene. Information literacy and the writing center. Computer and Composition 12(1995): 203-209.

[12] Sharon A. Weiner. Institutionalizing Information Literacy. The Journal of Academic Librarianship 38 (sept.2012):287-293. 